\title{
ГЕОГРАФІЯ
}

UDC 631.4:445.4

Andriy Borisovich Achasov,

Doctor of Sciences (Agriculture), Associate Professor,

Head of the Department of Geodesy, Cartography and Geoinformatics,

V. V. Dokuchaiv Kharkiv National Agrarian University,

«Dokuchaevske-2», Kharkiv region, Kharkiv district, 62483,

e-mail: achasov.ab@gmail.com, https://orcid.org/0000-0003-2446-3707;

Alla Oleksandrivna Achasova,

$\mathrm{PhD}$ (Biology), Associate Professor,

National Scientific Center «A. N. Sokolovsky Institute of Soil Science and Agrochemistry»,

4 Chaykovskaya str., Kharkiv, 61024,

e-mail: alsisa971@gmail.com, https://orcid.org/0000-0002-6294-2445;

Arkadiy Oleksandrivich Siedov,

Senior Lecturer of the Department of Geodesy, Cartography and Geoinformatics,

V. V. Dokuchaiv Kharkiv National Agrarian University,

e-mail: shakhmet1985@gmail.com, https://orcid.org/0000-0003-0604-4015

\section{THE USE OF DIGITAL ELEVATION MODELS FOR DETAILED MAPPING OF SLOPE SOILS}

А. Б. Ачасов, А. О. Ачасова, А. О. Сєдов. ВИКОРИСТАННЯ ЦИФРОВИХ МОДЕЛЕЙ РЕЛЬЕФУ ДЛЯ ДЕТАЛЬНОГО КАРТОГРАФУВАННЯ СХИЛОВИХ ІРУНТІВ. Останнім часом у світі тривають активні пошуки нових підходів до картографування трунтів. Традииійні методики трунтового картографування, які спирались переважно на результати польових обстежень, не відповідають вимогам сьогодення. Стаття присвячена питанню ијирового картографування трунтів на основі використання ицфрових моделей рельєфу (ЦМР). На дослідному полігоні площею 5 га було проведено детальне польове трунтове обстеження в ході якого було закладено 7 розрізів та відібрано 56 зразків трунту з поверхні. 3 а результатами БПЛА-зйомки була побудована ЦМР з просторовою роздільною здатністю $20 * 20$ см. В дослідженнях був використаний методичний підхід до оиінки гідротермічних умов трунтоутворення шляхом геоінформаційного аналізу рель-

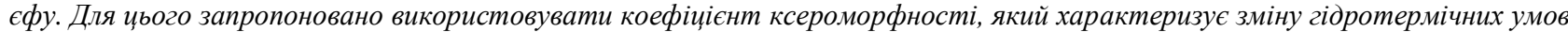
для конкретної ділянки рельєфу порівняно з горизонтальною поверхнею. На основі ЦМР було побудовано моделі крутості схилів та їх експозииї. Надалі отримані моделі були перетворені у модель ксероморфності території, яка характеризуе потенціал трунтоутворення досліджуваної місцевості. Аналіз даної моделі дозволив побудувати картограму потенційного вмісту органічного вуглецю в верхньому шарі трунтового покриву. В результаті порівняння даної картограми з картограмою фактичного вмісту органічного вуглецю була отримана кількісна оцінка ступеня деградаиї трунтового покриву та побудована детальна трунтова карта полігону. Отримана карта несе інформацію як про сучасний стан еродованих трунтів, так і про їхприродний потенціал. Встановлено, щчо середня втрата трунтами полігону органічного вуглецю внаслідок антропогенної деградаиії оцінюється у 5,1 кг на 1 m трунту.Застосування детальної карти, щзо побудована на вказаних методичних підходах дозволяє раціоналізувати господарське використання трунтів та оптимізувати заходи щодо їх реабілimaųii.

Ключові слова: трунт, карта, геоінформаційні системи, цифрова модель рельєфу, органічний вуглець, чорнозем, ксероморфноість, ерозія.

А. Б. Ачасов, А. А. Ачасова, А. А. Седов. ИСПОЛЬЗОВАНИЕ ЦИФРОВЫХ МОДЕЛЕЙ РЕЛЬЕФА ДЛЯ ДЕТАЛЬНОГО КАРТОГРАФИРОВАНИЯ СКЛОНОВЫХ ПОЧВ. В последнее время в мире ведутся активные поиски новых подходов к картографированию почв. Традиционные методики почвенного картографирования, которые опирались преимущественно на результаты полевых обследований, не соответствуют требованиям. Статья посвящена вопросу цифрового картографирования почв на основе использования иифровых моделей рельефа (ЦМР). На опытном полигоне площадью 5 га было проведено детальное полевое почвенное обследование, в ходе которого было заложено 7 разрезов и отобраны 56 образиов почвы с поверхности. По результатам БПЛА-съемки была построена ЦМР с пространственным разрешением $20 * 20$ см. В исследованиях был использован методический подход к оченке гидротермических условий почвообразования путем геоинформационного анализа рельефа. Для этого предложено использовать коэффиииент ксероморфности, который характеризует изменение гидротермических условий для конкретного участка рельефа по сравнению с горизонтальной поверхностью. На основе ЦМР были построены модели крутизны склонов и их экспозиции. В дальнейшем полученные модели были преобразованы в модель ксероморфности территории, которая характеризует потенциал почвообразования исследуемой местности. Анализ данной модели позволил построить картограмму потенциального содержания органического углерода в верхнем слое почвенного покрова. В результате сравнения данной картограммы с картограммой фактического содержания органического углерода была получена количественная оценка степени деградачии почвенного покрова и построена подробная почвенная карта полигона. Полученная карта несет информацию как о современном состоянии эродированных почв, так и об их природном потенциале. Установлено, что средняя потеря почвами полигона органического углерода в результате антропогенной деградации оценивается в 5,1 кг на 1 m почвы. Применение детальной карты, основан- 
ной на указанных методических подходах позволяет раџионализировать хозяйственное использование почв и оптимизировать мероприятия по их реабилитации.

Ключевые слова: почва, карта, геоинформационные системы, иифровая модель рельефа, органический углерод, чернозем, ксероморфность, эрозия.

Formulation of the problem. Rapid development of agrotechnologies requires their respective information support. First of all, it concerns available detailed and up-to-date soil cover information, which is the basis of agricultural production. This is especially true for Ukraine because, on the one hand, the agrarian sector is one of the main budgetforming branches of the country, and on the other hand, the mapping database of soils of Ukraine is very outdated. A solid large-scale survey of soils in Ukraine was carried out in the 1950's and 1960's, and the latest occasional soil map corrections date back to the 90's. Consequently, even the latest generation of ground maps in Ukraine has become outdated for at least 20 years.

In addition, it should be noted that even the second round of large-scale soil survey, using the old methods, does not fundamentally change the situation. A significant (albeit objective, at that time) drawback of the classic method of soil mapping, which was used in the USSR [1] and was at one time inherited by Ukraine [2], was a weak substantiation of the boundaries of the earth's habitats. The contours of the ground plots were applied to maps based on expert decisions of soil explorercartographers who used the materials of point field studies of the soil profiles, topographic maps and, sometimes, aerial photographs. Quantitative methods for deciphering aerial photographs and relief analysis, as a rule, were not used.

Modern agrarian production requires digital soil and agrochemical maps, representig the corresponding geospatial data bases. At the same time, the main importance of these maps should be the possibility to represent continuum of surface characteristics required by the user with the necessary detail and accuracy. Continuity of soil characteristics on such digital surface models (DSM) must be quantified. There are not so many ways to provide such a justification. Two spatial translators that can reliably transmit certain characteristics of the ground cover have already been named -remote sensing data in all of their modern manifolds, and landforms. Geostatistical capabilities for the construction of geopoles and vegetation as surface indicato are added.

Among all these sources of additional information on the soil cover, landforms are distinguished, which, unlike other factors, do not passively reflect the spatial diversity of soils, but is a factor in the formation of the surface structure by regulating the arrival of solar radiation and precipitation on the soil surface. It has been shown previously [3] that the topography factor can be considered as a determining one for the description of the variegated soil cover for the automorphic zonal soils in Ukraine in the scale of the administrative region.

Consequently, having a digital surface model (DEM) of the territory and established mathematical relationships between the parameters of the relief and soil characteristics, it is possible to create predictive TGKs. Subsequently, these maps are adapted to local conditions by adding auxiliary information (remote sensing data, archival and field data), and field verification.

Analysis of recent research and publications. Influence of the relief factor on the surface formation process has been known for a long time. P.A. Kostychev in his time, studying virgin steppe soils of Ukraine, showed that soils of the northern slopes are more humus-like, compared to the soils of southern exposures [4]. Specificity of soil formation on sloping lands was noted in the classical works of G.N. Vysotsky [5], D. Demek [6], A. Gerrard [7], P. Furley [8] and many others.

Development of computer and geoinformation technology has given this topic a powerful new impetus. According to Bishop and Minasny [9], almost $80 \%$ of digital soil mapping projects are performed using DEM as the most powerful source of data for forecasting local soil specificities.

DEM and its derivative geomorphological parameters can be used as the basic material for surface mapping in the following four ways:

1) To update the existing topographic maps.

The analysis of the literature provides numerous examples of the DEM use and derivative models for medium-sized and small-scale soil mapping [10, $11,12,13,14]$. A typical example is the work of Biggs and Slater [15] who carried out a mediumscale soil survey, using DEM and compared the results with an existing ground maps created by the traditional method. Using such topographic parameters as slope, surface curvature, topographic humidity index, relative height and slope position, a scale map of 1: 100000 was constructed, which allowed updating the existing map and increasing its reliability. Hammer et al. [16] have showed that the use of DEM with a spatial resolution of $10 \mathrm{~m}$ makes it possible to construct maps of slopes that have a large potential application for soil survey and land use planning.

2) For the allocation of soil-landscape units.

Two potential approaches to obtain ground land- 
scapes can be used. First, it is an automatic approach based on clustering $[17,18]$, when there are no definite criteria for the landscape classification. In these studies, an automated clustering procedure is used to determine meaningful clusters of the area, using a set of DEM derivatives. The second approach is based on compliance with the existing classification of landscapes, using expert assessment to determine the naming of selected landscapes according to the classification used [19]. Dobos et al. [20] identified the soil units according to the SOTER (World Soil Database) classification based on the analysis of the terrain by parameters such as height, relief and tilt. Hengl and Rossiter [21] applied photointerpretation in the reference regions for extrapolation of geomorphological units to the entire study area, using nine parameters of the relief.

3) For direct evaluation of soil parameters [22, $23,14,24,25]$.

The geomorphological parameters of the territory, as shown by the research [26, 27], can successfully be used to forecast the soil cover characteristics, as there is a dependable relationship between soil parameters and landforms characteristics. Geomorphological characteristics derived from DEM are increasingly used as auxiliary covariates for spatial prediction of soil properties [28, 29].

10 derivatives from DTM (STRM) were used in work [30] to assess organic carbon stocks in the soils of the Tibetan Highlands. It has been established that parameters such as altitude and slope length are closely related to the depth of the soil profile. M. Menezes and colleagues successfully used the DIM, derived from a topographic map of scale 1: 50000, and obtained a model for digital ground mapping of soils in Brazil from it [31]. A detailed review of the possible methods for forecasting soil parameters for DEM is presented by $\mathrm{T}$. Bishop and V. Minasny in [9].

4) To optimize the soil sampling strategy. Analysis of DEM with the allocation of homogeneous sections and key structural elements of the topography optimizes sampling schemes $[35,32]$ and minimizes the forecast error of individual soil parameters [36].

It should be noted that the use of DEM in soil research becomes much more effective if additional information is included in the analysis. Thus, in [37], it is indicated that using DEM together with information on the geological structure, makes it possible to forecast the types of soils in the studied territory. The expediency of the integral use of DEM with the data of remote sensing and other additional materials to improve the efficiency of soil mapping is confirmed in publications [12, 20,33,38].

Selection of previously unsettled parts of the general problem that the article focuses on. The literary review has showed that, despite a large number of publications, a lot of issues connected with surface digital mapping remain relevant.

In particular, individual geomorphological parameters are used in assessing the influence of topography on soil formation processes: altitude, exposition, steepness, slope length, topographic humidity index, curvature, topographic position index $[39,40,41,10,42]$ or their combination as a set of regression equations.

In our opinion, this is a logical but not optimal way of formalizing the effect of relief on soil formation. Such an approach does not allow the transition from empirical observations to a truly effective analysis of landscape-soil dependencies. The systematic approach is an alternative, taking into account the impact of relief not as a set of individual indicators, but as an integral function, which largely determines soil development [3].

It has also been noted that most of the wellknown publications refer to medium- and smallscale soil mapping. The use of geomorphological characteristics in large-scale and detailed mapping is given much less attention to. Although for today's agrarian production the most important are maps of scale 1: 5000 and larger.

Formulating the purpose of the article (statement of the task). The purpose of the article is to study the use of topographic indicative models in creation of detailed digital surface mapping materials.

Presentation of the main research material. Object and research methods. The research was carried out in 2016-2017 on the territory of the testing ground located on the lands of V.V. Dokuchaiv Kharkiv National Agrarian University. The experimental site is located on the slope of the southeastern exposition. The ravine divides the territory of the landfill into two sections - "fields". Field №1 is northeastern with the area of 5 hectares, field number 2 is southwestern with the area of $4.3 \mathrm{hec}-$ tares (Fig. 1). Major studies were focused on field number 1 .

Soil cover of the landfill was studied according to generally accepted methods [10] by laying out and describing 7 soil sections, as well as by additional selection of 64 soil samples from the surface.

Soil samples were selected according to two schemes: a regular network with a distance of approximately $50 \mathrm{~m}$, and an irregular one - for visually detected drainage basins. The sampling points were fixed (tied to the geographical coordinate system) using the GPS device.

In all samples, the content of organic matter (C) was determined for [43]. It is an important invariant characteristic of the soil and can serve as a reliable indicator of its condition. The soil samples were ana- 


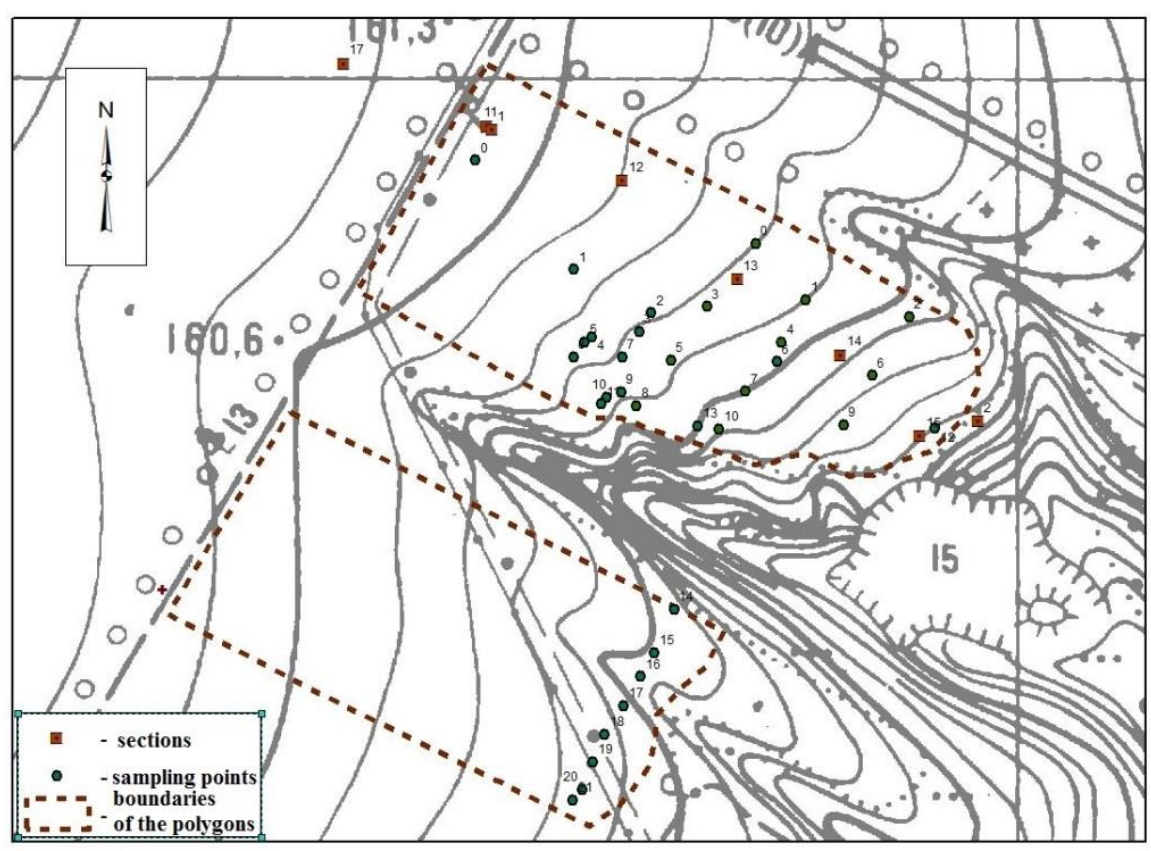

Fig. 1. Territory of the studied landfill

lysed in a certified laboratory of mass analyzes at the NSC "O.N. Sokolovsky ISS."

To analyze the influence of landforms on soil formation at the local level and the use of its characteristics in the digital surface mapping, a detailed digital model of the landfill site topography was used. The DEM spatial resolution is $20 \mathrm{x} 20 \mathrm{~cm}$ per pixel.

The digital surface model was built on the photography from an unmanned aerial vehicle DJI "Phantom 3Advanced". The shooting took place on June 22, 2016, at a height of $25 \mathrm{~m}$. With the help of the specialized mobile application "Pix4D Capture", an autopilot with overlapping of $80 \%$ of photos and average speed was created. The resolution of the pictures was $5 * 5 \mathrm{~cm}$. The received photos and construction of DEM were processed in the program "AgisoftPhotoScan" [44]. Subsequent analysis of the DEM was performed, using the ArcGIS software package.

Research results. The best description of any phenomenon or a process is a mathematical model based on well-defined physical laws. The first step towards formalization of the soil formation process in automorphic zonal non-aerated soils of Ukraine can be considered parametrization of two main substance-energy agents in soil formation: solar energy and moisture, incoming to the ground. According to [3], should the granulometric composition of the soil layer varies slightly, hydrothermal conditions of soil formation are completely controlled by the topography of the investigated area.

According to the results of the morphological description of soil sections and analysis of soil sam- ples, it has been established that the soil cover of the landfill is represented by chernozem typical with different degrees of erosion. The depth of the humus horizon $(\mathrm{H})$ of the soil gradually decreases down the slope from 51 to $30 \mathrm{~cm}$, which may be due to both the soil erosion and their xeromorphism, caused by specific sloping conditions of soil formation. The soil-forming rock for the territory of the landfill is heavy-sandy carbonate loess-like loam (the average content of particles is $<0.01 \mathrm{~mm}$ is $47.7 \%$ ). Thus, the process of soil formation before the beginning of active human activity was mainly controlled by topography.

To quantify this effect, it is suggested to use xeromorphism coefficient (Kc) [40], which characterizes the change of hydrothermal conditions for a specific landforms site in comparison with the horizontal surface:

$$
\mathrm{Kk}=\mathrm{Ki} / \mathrm{Kz}(1),
$$

where $\mathrm{Ki}$ is insolation coefficient, determining direct solar radiation on the real slope compared with the horizontal surface;

$\mathrm{Kz}$ is the relative humidity coefficient, characterizing the flow of moisture to the soil on this slope compared with the horizontal surface.

The calculating method of the reduced coefficients is presented in works [45, 46, 34]. The coefficients can be used to calculate the absolute values of solar radiation and precipitation for specific slopes, as well as the relative parameters that characterize the spatial soil-forming "potential" of the terrain.

It should be noted that $\mathrm{KK}$ is by its very nature close to the radiation index of dryness, widely used in geography to assess the climatic conditions of the 
terrain formation. The xeromorphity coefficient obtains its physical meaning if it is modified as a ratio with numerator equal to the product of the annual radiation balance on $\mathrm{Ki}$, and denominator is the product of the Kz per year of the amount of precipitation and the latent energy of steam generation. As a result, the analogue of the Grigoriev-Budiko dryness index for local landscapes is obtained.

It is clear that Kk can not fully reflect the influence of topography on soil formation, but in the first approximation it allows to quantify hydrothermal conditions at each point of the relief. The effectiveness of Kc use in the study of soil cover has been confirmed for the conditions of the Steppe and For- est-steppe of Ukraine. It has been established that Qk in non-eroded soils is closely related to the content of humus in black earths and the depth of their profile [45], and, accordingly, can act as a predictor in ground mapping [43].

Based on the results of the UAV-shooting of the DEM landfill (Fig. 2), derivative models were built by ArcGIS program of the following relief parameters: slope steepness, exposure, insolation coefficient $(\mathrm{KI})$, hydromorphic coefficient $(\mathrm{Kg})$, xeromorphic coefficient $(\mathrm{Kc})$. Table 1 shows statistical characteristics of these parameters for sites where samples of soil were selected.

The model of soil xeromorphism became the

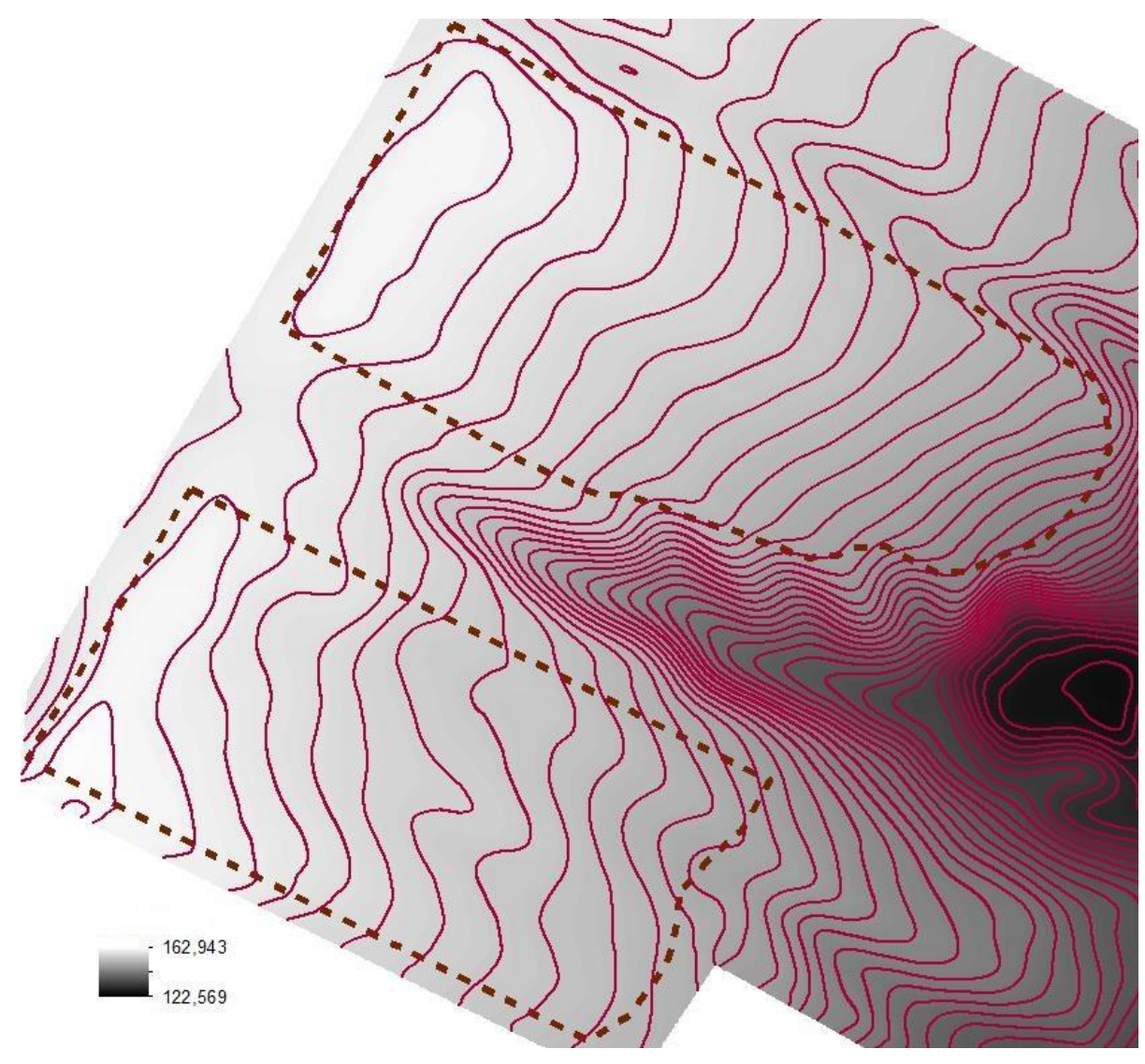

Fig. 2. DEM of experimental testing ground

Characteristics of sampling sites

\begin{tabular}{|l|c|c|c|c|c|}
\hline \multicolumn{1}{|c|}{ Variable } & Arithmetic mean & Minimum value & Maximum value & $\begin{array}{c}\text { Standard } \\
\text { deviation }\end{array}$ & $\begin{array}{c}\text { Variation } \\
\text { coefficient }\end{array}$ \\
\hline Steepness & 3,1 & 0,7 & 5,8 & 1 & 32 \\
\hline Exposition & 125 & 55 & 161 & 25 & 20 \\
\hline Hight & 155 & 144 & 161 & 3 & 2 \\
\hline $\mathrm{Ki}$ & 1,028 & 0,958 & 1,073 & 0,021 & 2 \\
\hline $\mathrm{K} \Gamma$ & 0,891 & 0,802 & 0,975 & 0,033 & 3 \\
\hline $\mathrm{K \kappa}$ & 1,156 & 1,026 & 1,337 & 0,058 & 5 \\
\hline $\mathrm{C}_{1}$ & 2,1 & 1,3 & 2,9 & 0,3 & 13 \\
\hline $\mathrm{C}_{2}$ & 2,7 & 2,2 & 3,1 & 0,2 & 6 \\
\hline
\end{tabular}

Note: $\mathrm{C}_{1}$ - the content of organic carbon in a layer of soil 0-10 cm, obtained analytically; $\mathrm{C} 2$ - the content of organic carbon in a layer of soil $0-10 \mathrm{~cm}$, calculated on the model of xeromorphism. 
spatial base for the creation of cartograms of organic carbon content in the upper layer of the landfill (Fig. $3)$. The calculation was based on logic-statistical models established earlier for a large sample (164 sections) of non-aerated soils [45, 46].

Since most of the samples on the territory of the landfill (56 pcs.) was selected on field number 1 , all the illustrations will characterize it in future.

Correlation analysis has showed that for the landfill territory there is no significant link between values of $\mathrm{C} 1$ content and relief parameters (Table 2). There is no link between $\mathrm{C} 1$ and the calculated carbon content $(\mathrm{C} 2): \mathrm{r}=-0.04$, either.

Comparing $\mathrm{C} 1$ and $\mathrm{C} 2$ values by 56 points, it

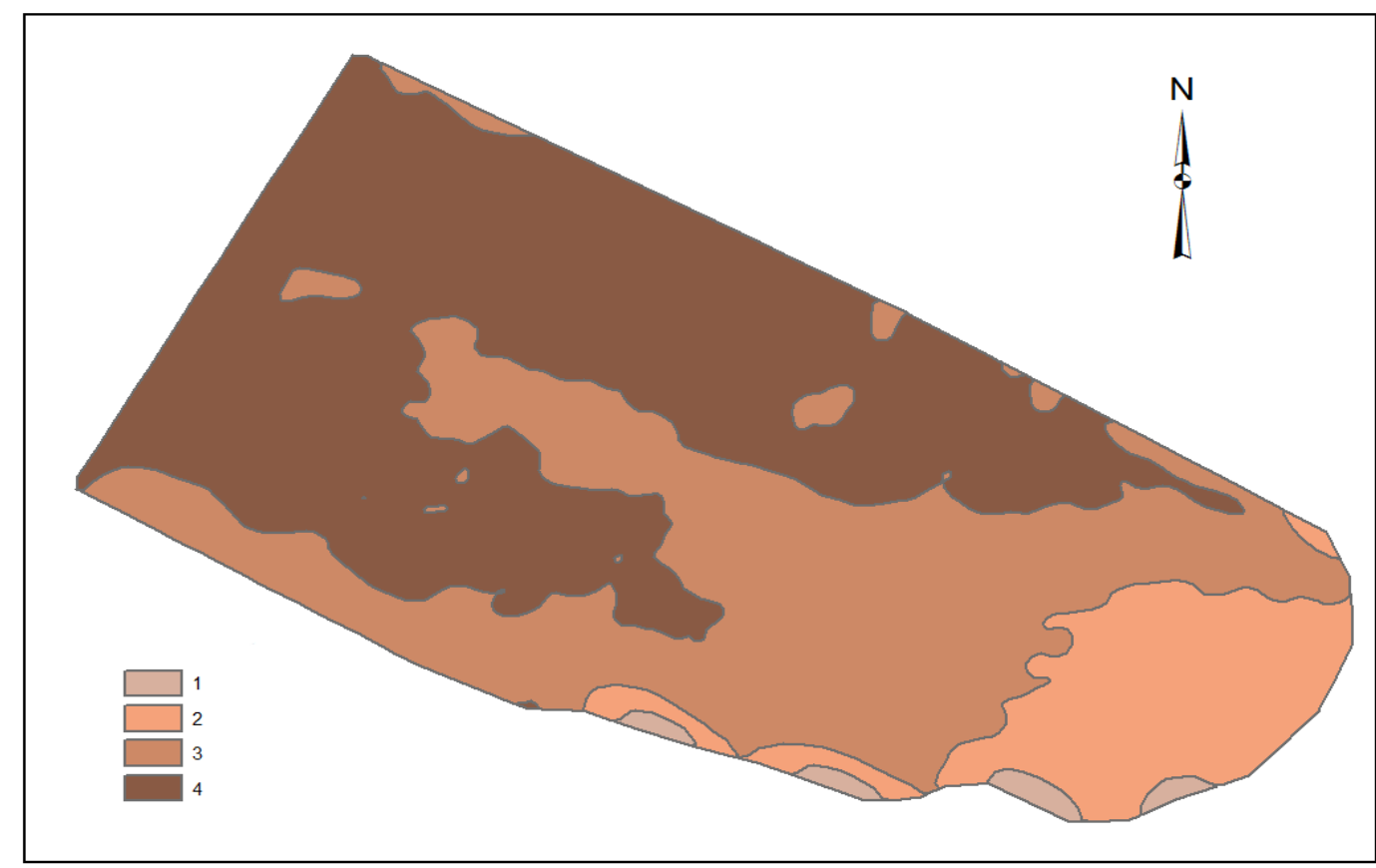

Fig. 3. The cartogram of organic carbon potential content in the upper layer of soil (C2) is constructed by method of geoinformation analysis of the landforms.

Symbols: 1) C2 <1.7\%; 2) C2 $=1.7-2.4 \%$; 3) C2 $=2.4-4.7 \%$; 4) C2> 2.7

Table 2

Results of correlation analysis

\begin{tabular}{|l|c|c|c|c|c|c|c|c|}
\hline & $\mathrm{C}_{1}$ & $\mathrm{C}_{2}$ & $\mathrm{Kk}$ & $\mathrm{Ki}$ & $\mathrm{K}_{\Gamma}$ & Exposition & Steepness & Hight \\
\hline $\mathrm{C}_{1}$ & 1 & $-0,04$ & $-0,04$ & 0,23 & 0,08 & 0,27 & $-0,08$ & 0,11 \\
\hline $\mathrm{C}_{2}$ & $-0,04$ & 1 & $-0,99$ & $-0,71$ & 0,91 & $-0,52$ & $-0,91$ & 0,69 \\
\hline
\end{tabular}

has been proved that the cartogram obtained during the geoinformation modeling, demonstrates the value of organic carbon content on average by $0.51 \%$ higher than the values established analytically in the soil survey. Moreover, the difference between the maximum values in the samples of the predicted and actually existing content $\mathrm{C}$ was only $0.2 \%$, while the minimum values of $\mathrm{C}$ for the two samples differed by $0.9 \%$.

This is absolutely logical because the cartographic materials obtained by the proposed algorithm for calculating the content of organic carbon reflect the situation of natural soil formation, without taking into account modern anthropogenic degradation of the soil. That is, they reflect natural potential of the soil. Loss of the upper layer of soil as a result of erosion processes leads to a decrease in $\mathrm{C}$ in the layer of soils in proportion to the degree of their erosion.

Having studied changes in the depth profile of the soil under the transect located along the slope (Figure 4), it has been established that the depth of the humused part of the profile (horizons $\mathrm{H}+\mathrm{Hr}$ ) of the arable soil gradually reduces due to decrease in the absolute height of the surface, indicating the influence of water erosion processes.

At the same time, section №2, located $10 \mathrm{~m}$ below the margin of the field in the area under virgin steppe vegetation, on the contrary, is characterized by super-high value of the humus part in the profile. Studies have shown that a solid layer of darkcolored humus soil is revealed at a depth of $200 \mathrm{~cm}$. The reason for this is a sharp decrease in the rate of water flow in the area covered with herbaceous ve- 


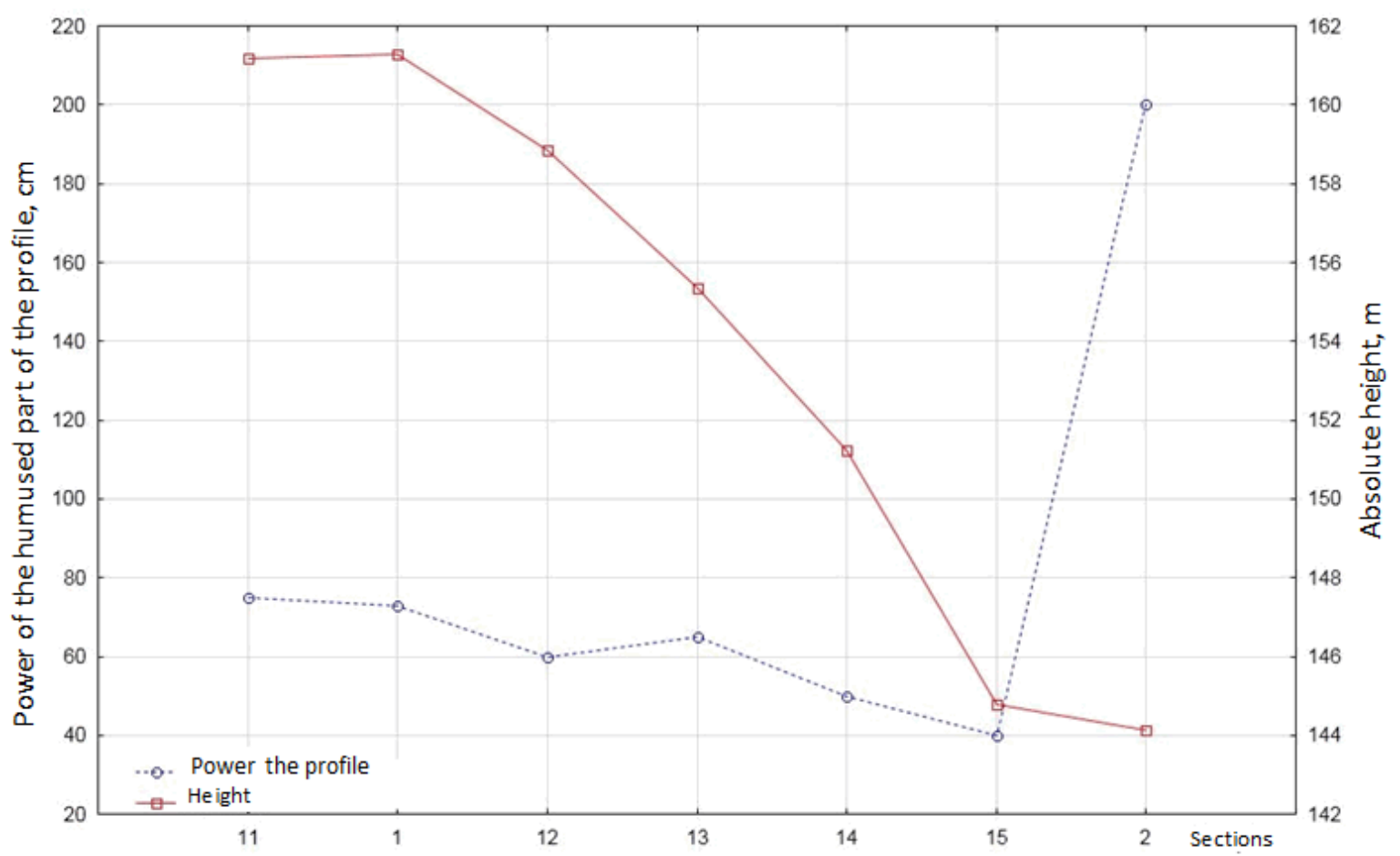

Fig.4. Change in depth of a landfill soil on height

getation, which contributes to the deposition of soil particles taken from the above cultivated slope.

Another confirmation of the erosion transformation of the landfill sites is the fact that the variation coefficient for the sample of calculated values $\mathrm{C}$ is half the coefficient of variation for the analytical values (Table 1). Indeed, the studied fields have practically the same constant exposure, which determines the weak spatial variability of solar radiation arrival on the surface. Accordingly, the process of organic matter formation in soils should be more homogeneous for the entire study area.

Consequently, the difference between the estimated and actual values of the $\mathrm{C}$ content in the upper layer of the landfill and absence of significant correlations of the actual carbon content with the relief parameters are associated with water erosion processes. This leads to a dynamic complex of washed away slope soils whose genesis is caused by the simultaneous influence of water erosion and sloping xeromorphism.

Furthermore, an actual cartogram of content $\mathrm{C}$ was constructed according to the laboratory measurements with the help of the ArcGIS program (Fig. 5).

The basis for cartograms was the value of $\mathrm{C}$ for 56 points located on field number 1 . Interpolation was carried out using the method of weighted distances. Spatial structure of the content $\mathrm{C}$ in the upper layer of soils of the landfill also confirms a significant degree of their transformation under the influence of erosion processes.
Comparison of the obtained cartograms (Figures 3 and 5) allows to construct a detailed map of the landfill grounds. The algorithm for constructing such a map is as follows:

1) To establish the correspondence between $C$ contents in a layer $0-10 \mathrm{~cm}$ and the degree of soil wash off. For this purpose, a standard characteristic of the $\mathrm{C}$ content distribution on the depth in the immutable soil is used. In our studies it was section number 20, which was laid outside the testing ground in the watershed and represented a typical modal chernozem. The diagnostic feature of weakly washed off soils is the erosion occupying half thickness of the humus accumulative horizon N. Accordingly, we assume that for our landfill value $\mathrm{C}$ in the upper layer of immutable soils should be more than $2.7 \%$, for weakly washed off soils it should fluctuate in the range of $2.4-2,7 \%$.

Average -washed soils are characterized by washing off from half to the entire horizon N. Content $\mathrm{C}$ in the upper layer of such soils varies within $1.7-2.4 \%$. Heavily washed soils, in which there is no horizon $\mathrm{H}$ and part of the upper transition horizon, are characterized by value of $\mathrm{C}<1.7 \%$. We used these ranges in the construction of cartograms $\mathrm{C}$ (Figures 3 and 5).

2) Overlaying of cartograms 3 and 5 in order to select all soil habitats formed on the crossing of the initial data.

3) Ground identification of the received mapdiagram (Fig. 6). It is based on the following logical considerations: 


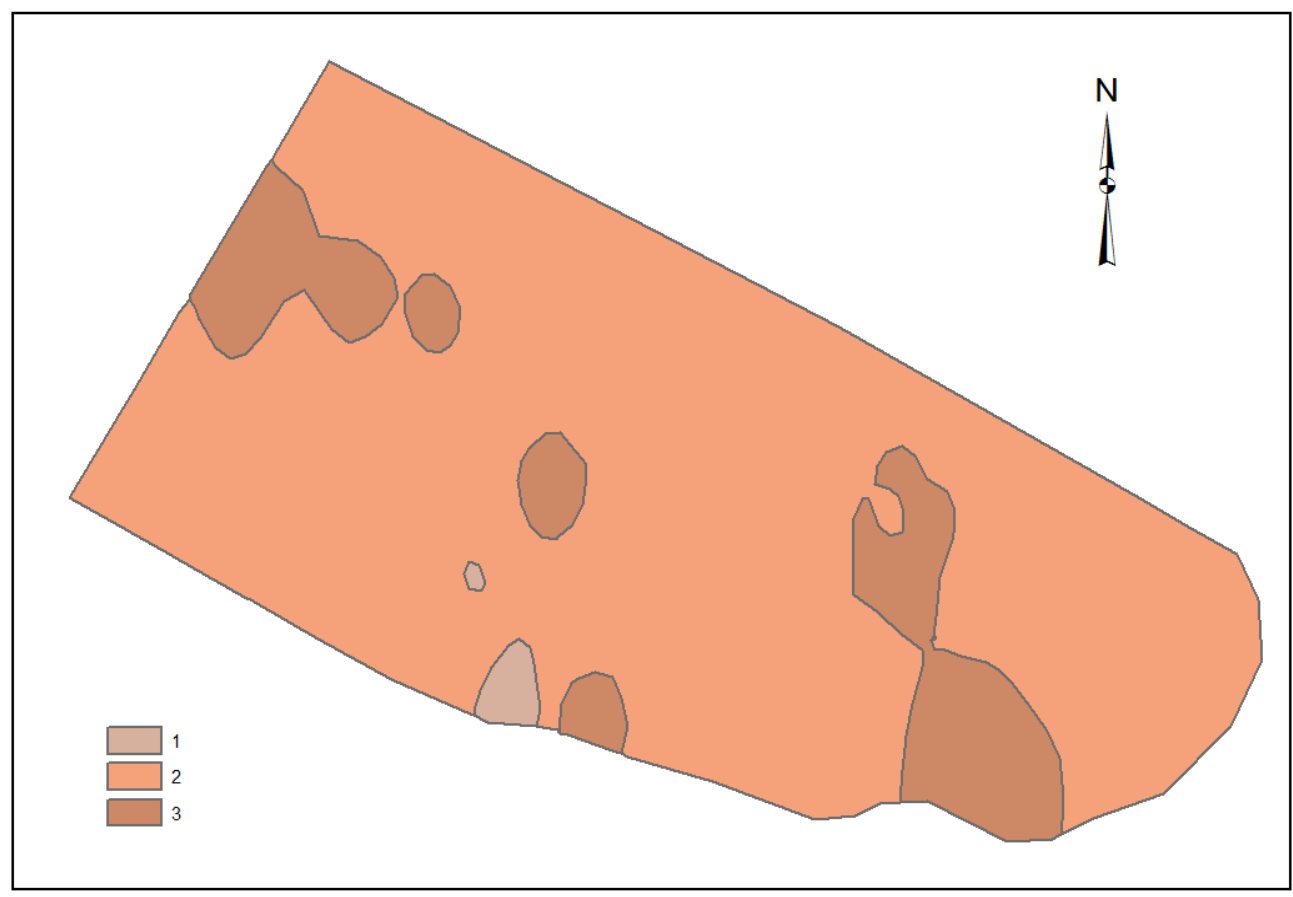

Fig. 5. Cartogram of the actual content of organic carbon in the upper layer of soil (C1), constructed by method of weighted distances.

Symbols: $\mathrm{C} 1<1.7 \%$; 2) C $1=1.7-2.4 \%$; 3$) \mathrm{C} 1=2.4-2.7 \%$.

The cartogram of the actual content of organic carbon (Fig. 5) can be interpreted as a map of soil erosion, where area № 1 corresponds to the heavily washed off soils, area № 2 - medium washed off soils and area № 3- weakly washed off chernozem.

The cartogram of the estimated potential content C (Fig. 3) reflects the quasi-solid state of soils, in which the erosion processes are a priori absent. Thus, the four distinct areas characterize not erosion but specific sloping hydrothermal conditions, in which it is impossible to form soil similar to the ground of the plain. Such conditions are typical for, for example, southern slopes of great steepness. Such underdeveloped soils have recently been named xenomorphic [47]. Accordingly, area № 1 corresponds to heavily xenomorphic, area № 2 average xenomorphic, area № 3 - weakly xenomorphic and area № 4 - modal chernozem.

The resultant forecasting map of soils is given in Fig. 6. It describes the soil cover of the field in more details, taking into account both its present condition and the soil formation potential. The map looks rather unusual. This is due to the detailed received information and the variability of the ground cover of the landfill.

Let us summarize the obtained results. The cartogram of potential content C (Fig. 5), constructed on the basis of the DEM analysis, reflects the initial state of the soil, or in other words, shows the "potential of the soil". It is, in fact, the standard to compare the parameters of modern soils to assess the degree of their degradation. Thus, the average loss of the organic carbon by the landfill soil due to anthropogenic degradation can be estimated at $0.51 \%$ by weight, that is, $5.1 \mathrm{~kg}$ per 1 ton of soil.

Combination of such a "quasi-virgin" ground map with the results of modern field soil surveys can significantly increase the informative resulting map.

In particular, analysis of Fig. 3 allows us to conclude that the initial conditions of soil formation for the studied field varied slightly. Weak- and medium-xeromorphic chernozems were formed only in the lower part of the slope due to significant slopes. Anthropogenic erosion degradation of soils greatly complicated the structure of the soil, making it stochastic. Thus, the southern part of the field adjacent to the bottom of the slope,being rather steep, is characterized by a high content of organic carbon, which contradicts the logic of soil formation and indicates the redeposition of soil with high hums content that has been taken out of the upper part of the field.

The obtained map, based on the research, (Fig. 6) not only reflects the current condition of the soil, but also allows to approach the process of managing soil resources in a new way. As a result of such mapping we obtain spatial information. Based on it, we can distinguish between degraded but potentially fertile soils from soils whose low fertility is due to natural factors - unfavorable hydrothermal conditions. Accordingly, different approaches should be applied to the use of these soils and taking soil protection measures. 


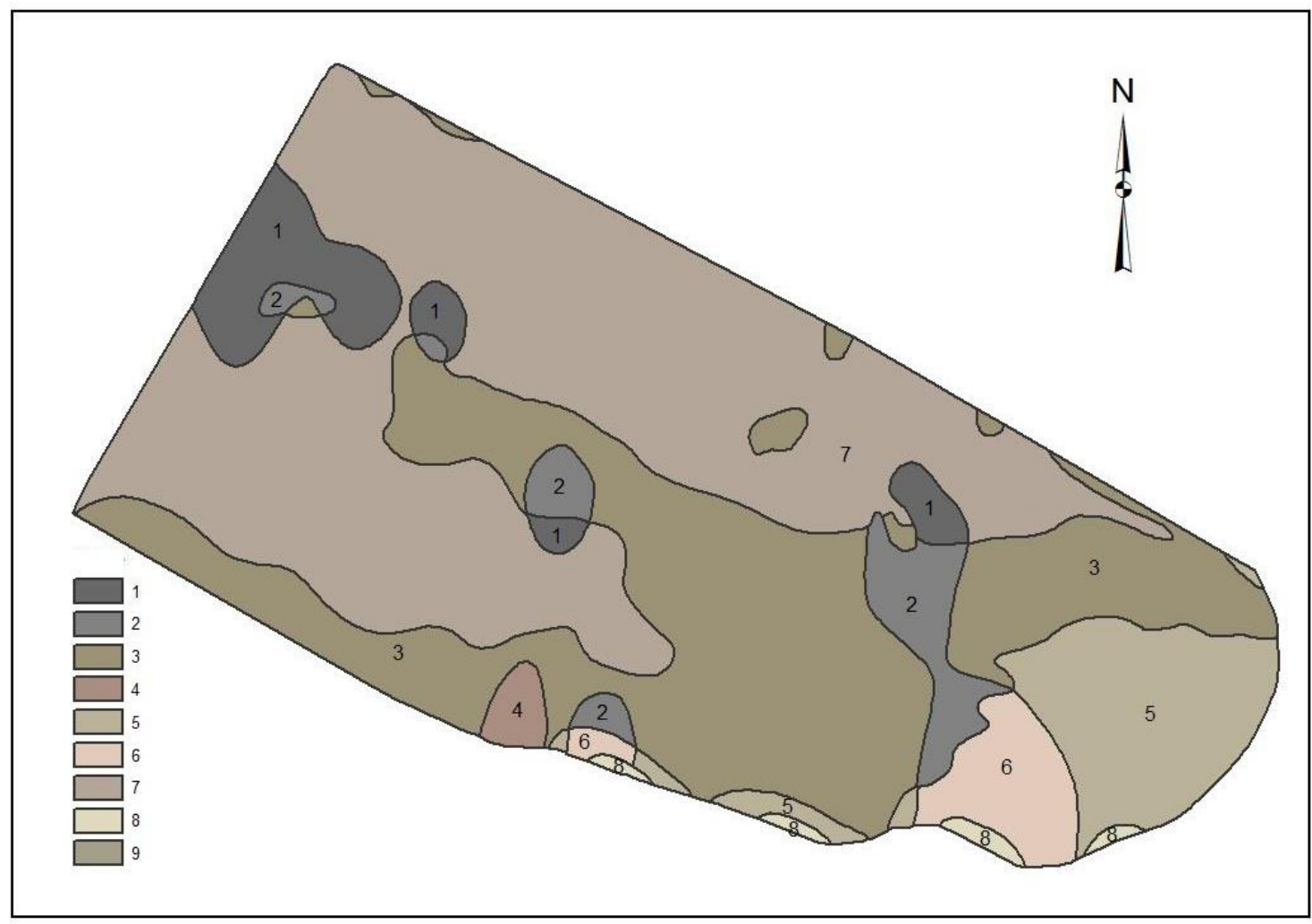

Fig. 6. Map of the landfill soils.

Symbols: 1 - chernozem typical weakly washed off, 2 - chernozem typical weakly xenomorphic, 3 - chernozem typical weakly xenomorphic and slightly washed off, 4 - chernozem typical weakly xenomorphic, medium washed off, 5 - chernozem typical medium xenomorphic, 6 - chernozem typical medium - xenomorphic,

alluvial; 7 - chernozem typical medium washed off, 8 - chernozem typical heavily xenomorphic alluvial

\section{Conclusion.}

1. Soils on slopes are formed in essentially different conditions in comparison with soils on the plain territories. Sloping soil formation is the result of a complex spatial combination of natural processes of xeromorphism, separation, transit and resedimentation of soil particles due to soil erosion. Therefore, it is necessary to use a fundamentally different approach in comparison with the soils of plain areas for correct mapping of slope soils. The combined effect of these processes should be taken into account.

2. Such an approach is used in geoinformation analysis of the terrain, making it possible to quantitatively formalize hydrothermal conditions of soil formation on the slopes and to spatially assess its xe- romorphism.

3. Mapping materials constructed on this methodical approach characterize the potential of the landscape in terms of soil formation and reflect the quasicyclical condition of the soil or "soil potential".

4. Detailed surface maps created by combination of the field and laboratory soil surveys results with the results of soil potential assessment for the analysis of DEM in the article make it possible to adequately estimate and objectively reflect distribution of eroded and xeromorphic soils and their complexes on sloping lands.

Acknowledgements. The authors are grateful for the assistance in carrying out UAV shooting and processing of the results to the company InteticsGeo and personally O. Seliverstov.

\section{References}

1. Общесоюзная инструкиия по почвенным обследованиям и составлению крупномасштабных почвенных карт землепользований [Текст]. - М.: Колос, 1973. - 94 c.

2. Тихоненко Д.Г. Картографія трунтів [Текст]: навч. посібник / Д. Г. Тихоненко, М. О. Горін, А. О. Георгі та ін.; за ред. Д. Г. Тихоненка // вид-во Харківський державний аграрний університет ім. В.В.Докучаєва. Харків, 2001. $-321 \mathrm{c}$.

3. Ачасов А.Б. Грунтово-геоінформачійні засади протиерозійної оптимізацї агроландшафтів: теорія $і$ практика: автореф. дис. на здобуття наук. ступеня докт. сільс. наук: спец. 06.01.03 «Агрогрунтознавство і агрофізика» [Текст] / А.Б. Ачасов - Київ, 2009. - 40 с.

4. Костычев П. А. Почвы черноземной области России, их происхождение и состав [Текст] / П. А. Костычев. - М.: Гос. изд-во сельскохоз. лит-ры, 1949. - 239 с. 
5. Высоцкий Г. Н. Об ороклиматических основах классификации почв [Текст] / Г. Н. Высочүкий // Почвоведение. -1906. - № 1. - С. 1-18.

6. Демек Я. Теория систем и изучение ландиафтов [Текст] / Я. Демек ; пер. с чеш. К. Г. Тарасов. //ПрогрессМ., 1977. - 223 c.

7. Джеррард А. Дж. Почвы и формы рельефа [Текст] / А. Дж. Джеррард ; пер. с англ. Р. В. Фурсенко, Е. М. Видре. - Недра. - Л., 1984. - 204 c.

8. Furley P. Relationships between slope form and soil properties developed over chalk parent materials [Teкcm] // Slopes, from and process. Ins. Br. Geograp. Spes. Publ. - 1971. - № 3. - P. 141-146.

9. Bishop, T.F.A. Digital soil-terrain modelling: the predictive potential and uncertainty [Teкcm]/ T.F.A. Bishop, B.Minasny // Environmental Soil-Landscape Modeling: Geographic Information Technologies and Pedometrics. CRC Press, Boca Raton, FL. - 2005. - P. 185-213.

10. Aksoy, E. Soil Mapping Approach in GIS using Landsat Satellite Imagery and DEM Data [Електронний pecypc]/E. Aksoy, G. Özsoy, S.M. Dirim // Data. African Journal of Agricultural Research. - 2009. - Vol. 4. - P. 1295-1302. - Pежим доступу: http://www.academiciournals.org/iournal/AJAR/article-abstract/D00C9C238184.

11. Ming, Z. Application of Satellite Remote Sensing to Soil and Land Use Mapping in the Rolling Hilly Areas [Tekcm] / Z. Ming, R. Goosens, L. Daels// EARSeL Advances in Remote Sensing - 1993.- Vol. 2. - P. 34-44.

12. Dobos, E.Use of Combined Digital Elevation Model and Satellite Radiometric Data for Regional Soil Mapping[Електронний ресурс] / E.Dobos, E.Micheli, M.F.Baumgardner, L.Biehl, T.Helt// Geoderma. - 2000. vol.97 - P. 367-391. - Pежнuм docmyny: https://doi.org/10.1016/S0016-7061(00)00046-X

13. Dobos, E.A Regional Scale Soil Mapping Approach using Integrated AVHRR and DEM Data[Електронний ресурс]/ E.Dobos, L.Montanarella, T.Negre, E.Erika Micheli //International Journal of Applied Earth Observation and Geoinformation. - 2001. - vol.3. - P.30-42. - Pежнu docmyny: https://doi.org/10.1016/S0303-2434(01)85019-4.

14. Bell, J.C.Soil Drainage Class Proba-bility Mapping using a Soil-Landscape Model[Електронний pecypc] / J.C.Bell, R.L.Cunningham, M.W. Havens // Soil Science Society of America Journal. - 1994. - Vol.58. - P.464-470. - Pежим docmyny: https://doi.org/10.2136/sssai1994.03615995005800020031x.

15. Biggs, A.Using soil landscape and digital elevation models to provide rapid medium scale soil surveys on the Eastern Darling Downs, Queensland [Teкcm] / A.Biggs, B.Slater// Proceedings of the 16th World Congress of Soil Science. - 1998. - Montpellier, France.

16. Hammer, R.D. Slope class maps form soil survey and digital elevation models [Teкcm] / R.D. Hammer, N.C. Young, T.L. Wolenhaupt, T.L. Barney, T.W. Haithcoate // Soil Sci. Soc. Am. J. - 1995. - vol.59. - P.509-519.

17. Bathgate, J.D.A geographic information systems based landscape classification model to enhance soil survey: a southern Illinois case study [Текст] /J.D.Bathgate, L.A.Duram // Journal of Soil and Water Conservation. - 2003. - Vol.58 (3). - P.119-127.

18. J.Schmidt. Multi-scale landform characterization [Tексm] / J.Schmidt, R.Andrew // Area. - 2005. - Vol. 37. P.341-350.

19. MacMillan, R.A.Automated analysis and classification of landforms using high-resolution digital elevation data: applications and issues [Tекcm] /R.A.MacMillan, T.C.Martin, T.J.Earle, D.H.McNabb // Canadian Journal of Remote Sensing. - 2003. - Vol.29 (5). - P. 592-606.

20. Dobos, E.An SRTM-based procedure to delineate SOTER Terrain Units on 1:1 and 1:5 million scales[Eлектронний pecypc] / E.Dobos, J.Daroussin, L.Montanarella // EUR - Scientific and Technical ResearchReports. - 2005. - Luxembourg. - Режим достуny: https://ec.europa.eu/jrc/en/publication/eur-scientific-and-technical-researchreports/srtm-based-procedure-delineate-soter-terrain-units-11-and-15-million-scales.

21. Hengl, T.Supervised landform classification to enhance and replace photointerpretation in semi-detailed soil survey [Teкcm] / T.Hengl, D.G.Rossiter // Soil Science Society of America Journal. - 2003. - vol.67 (5). - P. 1810-1822.

22. Moore, I.D.Soil Attribute Prediction using Terrain Analysis[Електронний pecypc] / I.D.Moore, P.E. Gessler, G.A.Nielson //Soil Science Society of America Journal. - 1993. - Vol. 57. - P. 443-452. - Pежним доступy: https://doi.org/10.2136/sssai1993.03615995005700020026x.

23. Gessler, P.E.Modelling Soil Landscape and Ecosystem Properties using Terrain Attributes[Електронний ресурс] / P.E.Gessler, O.A.Chadwick, F.Chamran, L.Althouse, K.Holmes // Soil Science Society of America Journal. - 2000. - vol.64. - P. 2046-2056. - Pежсuи docmyny:https://doi.org/10.2136/sssai2000.6462046x.

24. Hammer, R.D.Slope Class Maps form Soil Survey and Digital Elevation Models[Електронний pecypc] / R.D. Hammer, N.C.Young, T.L.Wolenhaupt,T.L.Barney, T.W.Haithcoate // Soil Science Society of America Journal. - 1995. vol.59. - P. 509-519. - Режни docmyny:https://doi.org/10.2136/sssai1995.03615995005900020034x.

25. Ачасов А. Б. К вопросу влияния рельефа на гумусированность черноземов [Текст] / А. Б. Ачасов // Почвоведение. -2006. - № 9. - C. 931-938.

26. McKenzie, N.J.Spatial prediction of soil properties using environmental correlation [Teкcm] / N.J.McKenzie, P.J.Ryan, // Geoderma. - 1999. - Vol.89 (1-2). - P. 67-94.

27. McBratney, A.B.On digital soil mapping [Tекcm] / A.B.McBratney, M.L.Mendonça Santos, B.Minasny // Geoderma. - 2003. - Vol. 117 (1-2). - P. 3-52.

28. Kempen, B.Three-Dimensional Mapping of Soil Organic Matter Content using Soil Type-Specific Depth Functions[Електронний ресурс] / B.Kempen, D.J. Brus, J.J.Stoorvogel // Geoderma. - 2011. - Vol. 162. - P. 107123. - Режним доступy: https://doi.org/10.1016/j.geoderma.2011.01.010. 
29. Ten Caten, A.Spatial Resolution of a Digital Elevation Model Defined by the Wavelet Function[Електронний ресурс]/ A.Ten Caten, R.S.D.Dalmolin, F.A. Pedron, M.L.Mendonca-Santos // Pesquisa Agropecuaria Brasileira. - 2012. Vol. 47. - P. 449-457. - Режнu docmyny:https://doi.org/10.1590/S0100-204X2012000300018.

30. Yang, Ren-Min. Precise estimation of soil organic carbon stocks in the northeast Tibetan Plateаи [Електроннии pecypc] / Ren-Min Yang, Gan-Lin Zhang, Fei Yang, Jun-Jun Zhi, F. Yang, F. Liu, Yu-Guo Zhao, De-Cheng Li // Scientific Report. - 2016. - P. 1-10. - Pежим достуny: http://media.springernature.com/m685/natureassets/srep/2016/160224/srep218 42/pdf/ srep21842.pdf.

31. Duarte de Menezes, M. Knowledge-based digital soil mapping for predicting soil properties in two representative watersheds [Електронний ресурс] / M. D. de Menezes, S. H. G. Silva , C. R. de Mello, P. R. Owens, N. Curi //Scientia Agricola. - 2018. - Vol. 75. - Pежuм docmyny: http:// www.scielo.br/scielo.php?script= sci_arttext\&pid=S0103-90162018000200144.

32. Silva, S.H.G. Evaluation of Conditioned Latin Hypercube Sampling as a Support for Soil Mapping and Spatial Variability of Soil Properties [Електронний pecypc] / S. H. G. Silva, P. R. Owens, B. M. Silva, G. C. de Oliveira, M. D. de Menezes, L. C. Pinto, N. Curi // Soil Science Society of America Journal. - 2015. - vol.79(2), - P. 603-611. Режим доступy: https://www.researchgate.net/publication/273521274_Evaluation_of_Conditioned_Latin_Hypercube_Sampling_as_a_Support_for_Soil_Mapping_and_Spatial_Variability_of_Soil_Properties.

33. Sindayihebura, A. Comparing digital soil mapping techniques for organic carbon and clay content: Case study in Burundi's central plateaus [Електронний ресурс] / A. Sindayihebura, S. Ottoy, S. Dondeyne, M. Van Meirvenne, J. Van Orshoven // Catena. - 2017. - Vol. 156. - P. 161-175 - Режим доступу: https://www.sciencedirect.com/science/article/pii/ S034181621730125X.

34. Бульгин С.Ю. Использование интегрального анализа данных дистанционного зондирования и цүифровых моделей рельефа при картографировании почвенного покрова черноземной зонь [Електронний ресурс] / С.Ю. Бульгин, А.Б. Ачасов, Ф.Н. Лисеикий // Научные ведомости Белгородского государственного университета. - Серия: Естественные науки. - 2012. - Режим доступу: https:// cyberleninka.ru/article/n/ispolzovanie-integralnogo-analiza-dannyh-distan tsionnogo-zondirovaniya-i-tsifrovyh-modeleyreliefa-pri-kartografirovanii-pochvennogo.

35. Minasny, B.A conditioned Latin hypercube method for sampling in the presence of ancillary information [Teкcm] / B. Minasny, A.B. McBratney // Computers \& Geosciences. - 2006. - Vol. 32 (9). - P. 1378-1388.

36. Brus, D.J. Optimization of sample patterns for universal kriging of environmental variables [Teкcm] / D.J.Brus, G.B.M.Heuvelink // Geoderma. - 2007. - vol.138 (1-2). - P. 86-95.

37. Moore, I.D. Terrain analysis for soil-specific crop management. In proceedings book[Teкcm] / I.D. Moore, P.D. Gessler, G.A. Nielsen, G.A. Peterson//Soil Specific Crop Management. - 1992. - Minnesota Extension Service. 14-16 April. - P. 27-57.

38. Bayramin, I. Using geographic information system and remote sensing techniques in making pre-soil survey[Tекст] /I. Bayramin // In proceedings book, 15th Int. symposium on desertification ISD. Soil Sci. Society of Turkey. - 2001. - Konya, Turkey.

39. Лисечкий Ф. Н. Климатическая обусловленность почвообразования в Центральном Черноземье [Текст] / Ф. Н. Лисеикий, О. А. Чепелев // Вестник ВГУ. - Серия: География и геоэкология. - 2003. - № 2. - С. $15-23$.

40. Шпедт А. А. Влияние мезорельефа на продуктивность зерновых культур и плодородие чернозема Красноярской степи [Текст] / А. А. Шпедт, В. К. Пурлаур, Н. В. Михайленко, П. В. Кузьмин // Почвоведение. 2004. № 10. - C. 1228-1234.

41. Miller J. O. Soil Organic Carbon Content in Frigid Southern Appalachian Mountain Soils [Teкcm] /J. O. Miller, J. M.Galbraith, W. L.Daniels // Soil Sci. Soc. Am. J.-2004. -68:194. - 203 p.

42. Чинилин А.В. Крупномасштабное иифровое картографирование содержания органического углерода почв $c$ помощью методов машинного обучения [Текст] /А.В. Чинилин, И.Ю. Савин // Бюл. Почв. ин-та им. В.В. Докучаева. -2018. -Bыn. 91. -C. 46-62. https://doi.org/10.19047/0136-1694-2018-91-46-62.

43. Ачасов А.Б. Використання циифрових моделей рельєфу при дослідженні трунтового покриву [Текст]/ А.Б. Ачасов //ВісникХНАУ. Сер. «Ірунтознавство, агрохімія, землеробство, лісовегосподарство».-Х.: ХНАУ. 2008. -№ 1. -C. 157-159.

44. Сєдов А.О. Можливості використання БПЛА середнього иінового сегменту для картографування сільськогосподарських ресурсів [Текст]/ А. О. Сєдов// Вісник ХНУ імені В.Н. Каразхіна. Серія «Екологія». - 2018. вun. 18. C. 22-29.

45. Ачасов А.Б. Деякі аспекти формалізачії гідротермічних умов трунтоутворення [Текст]/ А.Б. Ачасов // Вісник аграрної науки. - 2006. - № 9. - С. 17-21.

46. Ачасов А. Б. К вопросу влияния рельефа на гумусированность черноземов [Текст]/ А. Б. Ачасов // Почвоведение. - 2006. - № 9. - С. 931-938.

47. Класифікація трунтів Украӥни [Текст] : за редакцією доктора сільськогосподарських наук М. I. Полупана / М. І. Полупан, В. Б. Соловей, В. А. Величко// ННЦ "Інститут трунтознавства та агрохімї імені О. Н. Соколовського. - Київ : [б. и.], 2005.

Authors Contribution: All authors have contributed equally to this work. 
UDC 631.4:445.4

\author{
Andriy Achasov, \\ Doctor of Sciences (Agriculture), Associate Professor, \\ Head of the Department of Geodesy, Cartography and Geoinformatics, \\ V. V. Dokuchaiv Kharkiv National Agrarian University, \\ «Dokuchaevske-2», Kharkiv region, Kharkiv district, 62483, \\ e-mail: achasov.ab@gmail.com, https://orcid.org/0000-0003-2446-3707; \\ Alla Achasova, \\ $\mathrm{PhD}$ (Biology), Associate Professor, \\ National Scientific Center «A. N. Sokolovsky Institute of Soil Science and Agrochemistry», \\ 4 Chaykovskaya str., Kharkiv, 61024, \\ e-mail: alsisa971@gmail.com, https://orcid.org/0000-0002-6294-2445; \\ Arkadiy Siedov, \\ Senior Lecturer of the Department of Geodesy, Cartography and Geoinformatics, \\ V. V. Dokuchaiv Kharkiv National Agrarian University, \\ e-mail: shakhmet1985@gmail.com, https://orcid.org/0000-0003-0604-4015
}

\title{
THE USE OF DIGITAL ELEVATION MODELS FOR DETAILED MAPPING OF SLOPE SOILS
}

Formulation of the problem. The current stage of agricultural development in Ukraine requires highly informative soil maps.

One of the directions for creating such maps is the use of digital elevation models (DEM) as a spatial translator of soil characteristics.

The literary review has showed that despite the large volume of publications on this topic, a number of issues of soils digital mapping remain relevant.

The purpose of the article is to study the possibilities of using relief-ground indicative models in creation of detailed digital ground maps.

Methods. The research was conducted on the territory of the testing ground. During the field study of the landfill, it has been established that the soils are represented by chernozem typical of varying erosion degrees.

It is proposed to use a xeromorphism coefficient for the quantitative account of the landforms influence on soil formation, characterizing changes in hydrothermal conditions for a particular section of the topography, compared with the horizontal surface.

A detailed DTM was obtained, using the "Phantom 3" UAV.The derivative models of a number of topographic parameters were built on its basis later. A digital model of xeromorphism of the territory was built, transformed into a model of organic carbon (C) content.

The specified map shows initial conditions of the soil cover. It can be used as a standard to compare parameters of modern soils for assessment of extent of their degradation.

Comparison of this map with the map of actual $\mathrm{C}$ content has shown that average loss of $\mathrm{C}$ by soils of the studied area owing to anthropogenic degradation can be estimated at $5.1 \mathrm{~kg}$ on $1 \mathrm{t}$ of the soil.

Results. Investigations have proved that the geoinformation analysis of landforms allows to quantitatively shape hydrothermal conditions of soil formation for a certain territory. The cartographic materials constructed on such a methodical approach characterize landscape potential on soil formations and reflect quasivirgin land condition of the soil.

Scientific novelty and practical significance. The detailed soil maps, based on the results of field and laboratory soil studies, leading to potential soil assessment for DEM analysis in the article, allow to adequately estimate and objectively represent distribution of eroded and xeromorphic soils and their complexes on sloping lands.

Keywords: soil, map, geographic information systems, digital surface model, organic carbon, chernozem soil, erosion.

\section{References}

1. Obschesoyuznaya instruktsiya po pochvennyim obsledovaniyam i sostavleniuy krupnomasshtabnyih pochvennyih kart zemlepolzovaniay [All-Union instructions for soil surveys and compilation of large-scale soil maps of land use] (1973). M, Kolos, 94.

2. Tykhonenko D.H., HorinM. O., HeorhiA. O. ta in. (2001). Kartohrafiia gruntiv[Cartography of soils]: navch. posibnyk za red. D. H. Tykhonenka, vyd-vo Kharkivskyi derzhavnyi ahrarnyi universytet im. V.V.Dokuchaieva. Kharkiv, 321 . 
3. Achasov A.B. (2009). Gruntovo-heoinformatsiini zasady protyeroziinoi optymizatsii ahrolandshaftiv: teoriia i praktyka [Soil-geoinformation principles of anti-erosion optimization of agro-landscapes: theory and practice]: avtoref. dys. na zdobuttia nauk. stupenia dokt. sils. nauk: spets. 06.01.03 «Ahrogruntoznavstvo i ahrofizyka». Kyiv, 40.

4. Kostyichev P. A. (1949). Pochvyi chernozemno yoblasti Rossii, ih proishozhdenie $i$ sostav [Soils of the chernozem region of Russia, their origin and composition]. M, Gos. izd-vo selskohoz. lit-ryi, 239.

5. Vyisotskiy G. N. (1906). Ob oroklimaticheskih osnovah klassifikatsiipochv [About the oroclimatic basis of soil classification]. Pochvovedenie, 1, 1-18.

6. Demek Ya (1977). Teoriya sistem i izuchenielandshaftov [Systems theory and studied of landscapes]. Progress. M., 223.

7. Dzherrard A. Dzh. (1984). Pochvyi i formyirelefa [Soil and landforms]. Nedra. L., 204.

8. Furley P. (1971). Relationships between slope form and soil properties developed over chalk parent materials. Slopes, from and process. Ins. Br. Geograp. Spes. Publ, 3, 141-146.

9. Bishop, T.F.A., Minasny, B. (2005). Digital soil-terrain modelling: the predictive potential and uncertainty. In: Grunwald, S. (Ed.), Environmental Soil-Landscape Modeling: Geographic Information Technologies and Pedometrics. CRC Press, Boca Raton, FL, 185-213.

10. Aksoy, E., Özsoy, G. and Dirim, S.M. (2009) Soil Mapping Approach in GIS using Landsat Satellite Imagery and DEM Data. African Journal of Agricultural Research, 4, $1295-1302$. http://www.academiciournals.org/iournal/AJAR/article-abstract/D00C9C238184

11. Ming, Z., Goosens, R. and Daels, L. (1993) Application of Satellite Remote Sensing to Soil and Land Use Mapping in the Rolling Hilly Areas. EARSeL Advances in Remote Sensing, 2, 34-44.

12. Dobos, E., Micheli, E., Baumgardner, M.F., Biehl, L. and Helt, T. (2000) Use of Combined Digital Elevation Model and Satellite Radiometric Data for Regional Soil Mapping. Geoderma, 97, 367-391. https://doi.org/10.1016/S00167061(00)00046-X.

13. Dobos, E., Montanarella, L., Negre, T. and Erika Micheli, E. (2001) A Regional Scale Soil Mapping Approach using Integrated AVHRR and DEM Data. International Journal of Applied Earth Observation and Geoinformation, 3, 3042. https://doi.org/10.1016/S0303-2434(01)85019-4

14. Bell, J.C., Cunningham, R.L. and Havens, M.W. (1994) Soil Drainage Class Proba-bility Mapping using a SoilLandscape Model. Soil Science Society of America Journal, 58, $464-470$. https://doi.org/10.2136/sssai1994.03615995005800020031x

15. Biggs, A., Slater, B. (1998). Using soil landscape and digital elevation models to provide rapid medium scale soil surveys on the Eastern Darling Downs, Queensland. In: Proceedings of the 16th World Congress of Soil Science. Montpellier, France.

16. Hammer, R.D., Young, N.C., Wolenhaupt, T.L., Barney, T.L. and Haithcoate, T.W. (1995). Slope Class Maps form Soil Survey and Digital Elevation Models. Soil Science Society of America Journal, 59, 509-519. https://doi.org/10.2136/sssai1995.03615995005900020034x

17. Bathgate, J.D., Duram, L.A. (2003). A geographic information systems based landscape classification model to enhance soil survey: a southern Illinois case study. Journal of Soil and Water Conservation, 58 (3), 119-127.

18. Schmidt, J., Andrew, R. (2005). Multi-scale landform characterization. Area 37, 341-350.

19. MacMillan, R.A.,Martin, T.C., Earle, T.J., McNabb, D.H. (2003). Automated analysis and classification of landforms using high-resolution digital elevation data: applications and issues. Canadian Journal of Remote Sensing, 29 (5), 592-606.

20. Dobos, E., Daroussin, J.,Montanarella, L. (2005). An SRTM-based procedure to delineate SOTER Terrain Units on 1:1 and 1:5 million scales, EUR 21571 EN. Office for Official Publications of the European Communities, Luxembourg, 55 .

21. Hengl, T., Rossiter, D.G. (2003). Supervised landform classification to enhance and replace photointerpretation in semi-detailed soil survey. Soil Science Society of America Journal, 67 (5), 1810-1822.

22. Moore, I.D., Gessler, P.E. and Nielson, G.A. (1993). Soil Attribute Prediction using Terrain Analysis. Soil Science Society of America Journal 57, 443-452. https://doi.org/10.2136/sssai1993.03615995005700020026x.

23. Gessler, P.E., Chadwick, O.A., Chamran, F., Althouse, L. and Holmes, K. (2000). Modelling Soil Landscape and Ecosystem Properties using Terrain Attributes. Soil Science Society of America Journal, 64, $2046-2056$. https://doi.org/10.2136/sssai2000.6462046x.

24. Hammer, R.D., Young, N.C., Wolenhaupt, T.L., Barney, T.L. and Haithcoate, T.W. (1995). Slope Class Maps form Soil Survey and Digital Elevation Models. Soil Science Society of America Journal, 59, 509-519. https://doi.org/10.2136/sssai1995.03615995005900020034x.

25. Achasov A. B. (2006). K voprosu vliyaniya relefa na gumusirovannost chernozemov[To the question of the influence of relief on the humus content of chernozem]. Pochvovedenie, 2006, 931-938.

26. McKenzie, N.J., Ryan, P.J. (1999). Spatial prediction of soil properties using environmental correlation. Geoderma, 89 (1-2), 67-94.

27. McBratney, A.B., Mendonça Santos, M.L., Minasny, B. (2003). On digital soil mapping. Geoderma, 117 (1-2), 3-52. 
28. Kempen, B., Brus, D.J. and Stoorvogel, J.J. (2011). Three-Dimensional Mapping of Soil Organic Matter Content using Soil Type-Specific Depth Functions. Geoderma, 162, $107-123$. https://doi.org/10.1016/j.geoderma.2011.01.010.

29. Ten Caten, A., Dalmolin, R.S.D., Pedron, F.A. and Mendonca-Santos, M.L. (2012). Spatial Resolution of a Digital Elevation Model Defined by the Wavelet Function. Pesquisa Agropecuaria Brasileira, 47, $449-457$. https://doi.org/10.1590/S0100-204X2012000300018.

30. Yang, Ren-Min, Zhang, Gan-Lin, Yang, F., Zhi, Jun-Jun, Yang,F.,Liu, F., Zhao, Yu-Guo,Li, De-Cheng.(2016). Precise estimation of soil organic carbon stocks in the northeast Tibetan Plateau. Scientific Report, 1-10. http://media.springernature.com/m685/nature-assets/srep/2016/160224/srep21842/pdf/srep21842.pdf.

31. Duarte de Menezes, M., Silva, S. H. G., de Mello, C. R., Owens, P. R., CuriN. (2018). Knowledge-based digital soil mapping for predicting soil properties in tworepresentative watersheds. Scientia Agricola, 75. http:// www.scielo.br/scielo.php?script=sci_arttext\&pid=S0103-90162018000200144.

32. Silva, S. H. G.,Owens, P. R., Silva, B. M., de Oliveira, G. C., Duarte de MenezesM., Pinto L. C., Curi N. (2015).Evaluation of Conditioned Latin Hypercube Sampling as a Support for Soil Mapping and Spatial Variability of Soil Properties. Soil Science Society of America Journal, vol.79(2), 603-611. https://www.researchgate.net/publication/273521274_Evaluation_of_Conditioned_Latin_Hypercube_Sampling_as_ a_Support_for_Soil_Mapping_and_Spatial_Variability_of_Soil_Properties.

33. Sindayihebura, A., Ottoy,S., Dondeyne, S., Van Meirvenne, M., Van Orshoven, J. (2017).Comparing digital soil mapping techniques for organic carbon and clay content: Case study in Burundi's central plateaus. Catena, 156, 161-175. https://www.sciencedirect.com/science/article/pii/S034181621730125X.

34. Bulyigin, S.Yu., Achasov, A.B., Lisetskiy, F.N. (2012). Ispolzovanie integralnogo analiza dannyih distantsionnogo zondirovaniya i tsifrovyih modeley relefa pri kartografirovanii pochvennogo pokrova chernozemnoy zonyi [The use of integral analysis of remote sensing data and digital elevation models for mapping the soil cover of the chernozem zone]. Nauchnyie vedomosti Belgorodskogo gosudarstvennogo universiteta. Seriya: Estestvennyie nauki. https://cyberleninka.ru/article/n/ispolzovanie-integralnogo-analiza-dannyh-distantsionnogo-zondirovaniya-itsifrovyh-modeley-reliefa-pri-kartografirovanii-pochvennogo.

35. Minasny, B., McBratney, A.B. (2006). A conditioned Latin hypercube method for sampling in the presence of ancillary information. Computers \& Geosciences, 32 (9), 1378-1388.

36. Brus, D.J., Heuvelink, G.B.M. (2007). Optimization of sample patterns for universal kriging of environmental variables. Geoderma, 138 (1-2), 86-95.

37. Moore ID, Gessler PD, Nielsen GA, Peterson GA (1992). Terrain analysis for soil-specific crop management. In proceedings book, A workshop on research and development issues, Minnesota Extension Service, 12-16 April, 27-57.

38. Bayramin I (2001). Using geographic information system and remote sensing techniques in making pre-soil survey. In proceedings book, 15th Int. symposium on desertification ISD. Soil Sci. Society of Turkey, 1317 June 2000 , Konya, Turkey.

39. Lisetskiy F. N., ChepelevO. A. (2003).Klimaticheskaya obuslovlennost pochvoobrazovaniya v Tsentralnom Chernozeme [Climatic conditionality of soil formation in the Central Chernozem Region]. Vestnik VGU.Seriya: Geografiya i geoekologiya, 2003, 2, 15-23.

40. Shpedt A. A., Purlaur V. K., Mihaylenko N. V., Kuzmin P. V. (2004). Vliyanie mezorelefa na produktivnost zernovyih kultur i plodorodie chernozema Krasnoyarskoy stepi [The effect of mesorelief on the productivity of grain crops and fertility of the chernozem soil of the Krasnoyarsk steppe].Pochvovedenie, 10, 1228-1234.

41. Miller J. O., Galbraith J. M., Daniels W. L. (2004). Soil Organic Carbon Content in Frigid Southern Appalachian Mountain Soils. Soil Sci. Soc. Am. J. 68:194, 203.

42. Chinilin A.V., Savin I.Yu. (2018). Krupnomasshtabnoe tsifrovoe kartografirovanie soderzhaniya organicheskogo ugleroda pochv s pomoschyu metodov mashinnogo obucheniya [Large-scale digital mapping of soil organic carbon content with using machine learning methods]. Byul. Pochv. in-taim. V.V. Dokuchaeva, 91, 46-62, doi: 10.19047/0136-1694-2018-91-46-62.

43. Achasov A.B. (2008). Vykorystannia tsyfrovykh modelei reliefu pry doslidzhenni gruntovoho pokryvu [Use of digital models of relief in the study of soil cover]. VisnykKhNAU. Ser. «Gruntoznavstvo, ahrokhimiia, zemlerobstvo, lisovehospodarstvo», 1, 157-159.

44. Siedov A.O. (2018). Mozhlyvosti vykorystannia BPLA serednoho tsinovoho sehmentu dlia kartohrafuvannia silskohospodarskykh resursiv [Possibilities of use of the UAVs of the average price segment for mapping of agricultural resources]. Visnyk KhNU imeni V.N. Karazkhina. Seriia «Ekolohiia», 18, 22-29.

45. Achasov A.B. (2006). DeyakI aspekti formalIzatsiyi gIdrotermIchnih umov gruntoutvorennya [Some aspects of the formalization of hydrothermal conditions of soil formation]. Visnik agrarnoyi nauki, 9, 17-21.

46. Achasov A. B. (2006). K voprosu vliyani yarelefa na gumusirovannost chernozemov [To the question of the influence of relief on the humus content of chernozem]. Pochvovedenie, 9, 931-938.

47.Polupan M. I., Solovei V. B., Velychko V. A. (2005). Klasyfikatsiia gruntiv Ukrainy [Classification of soils of Ukraine]: za redaktsiieiu doktora silskohospodarskykh nauk M. I. Polupana. NNTs "Instytut hruntoznavstva ta ahrokhimii imeni O. N. Sokolovskoho, Kyiv. 